\title{
The Concept of an Agricultural Surplus, from Petty to Smith
}

\author{
Anthony Brewer \\ Discussion Paper No. 08/602
}

April 2008

Department of Economics

University of Bristol

8 Woodland Road

Bristol BS8 1TN 


\title{
The Concept of an Agricultural Surplus, from Petty to Smith
}

\author{
Anthony Brewer ${ }^{1}$
}

\begin{abstract}
Everyone has to eat, so those who produce food must produce enough to feed themselves and to feed all those who do not produce their own food. Once stated. this is trivially obvious but, I will argue, making that simple relation between agriculture and the rest of the economy explicit and, at least in principle, quantifiable played a significant role in the development of economic thinking in the seventeenth and eighteenth centuries. This paper will focus on a very specific way of posing the question. Many of the most important economic writers of the period (Petty, Cantillon, Hutcheson, Hume, Steuart, Mirabeau, Smith and others) used arguments of the form: $x$ men can feed $y$, where $y>x$. A series of questions naturally follow. Will the surplus be produced at all? How is it transferred to those who consume it? What are the 'superfluous hands' (in Hume's terms) to do? It is impossible to pose these questions without thinking about the economy as a whole, and the way different sectors hang together. The common thread that runs through eighteenth-century discussions of surplus is a concern with the relation between industry and agriculture, and the potential for development arising from their interplay. There is, however, a clear discontinuity between the eighteenth-century view of agricultural surplus discussed here and the later tradition which links a concept of surplus to income distribution and pricing. Writers before Smith did not generally conceptualize income distribution in terms of the division of a defined total income between different functional shares, nor was there any consistent tradition linking income shares to the concept of an agricultural surplus as discussed here.
\end{abstract}

JEL: B12

Keywords: surplus, agriculture, William Petty, Richard Cantillon, David Hume, Adam Smith

\footnotetext{
${ }^{1}$ Dept of Economics, University of Bristol, 8 Woodland Road, Bristol BS8 1TN, UK. A.Brewer@bristol.ac.uk.
} 


\section{Introduction}

Everyone has to eat, so those who produce food must produce enough to feed themselves and to feed all those who do not produce their own food. Once stated. this is trivially obvious but, I will argue, making that simple relation between agriculture and the rest of the economy explicit and, at least in principle, quantifiable played a significant role in the development of economic thinking in the seventeenth and eighteenth centuries.

This paper will focus on a very specific way of posing the question. Many of the most important economic writers of the period (Petty, Cantillon, Hutcheson, Hume, Steuart, Mirabeau, Smith and others) used arguments of the form

$$
x \text { men }^{2} \text { can feed } y \text {, where } y>x(\text { Statement } 1 a),
$$

or the very similar

$x$ men can provide necessary subsistence for $y$, where $y>x$ (Statement $1 b)$,

with the obvious corollary that $y-x$ can be fed (or provided with subsistence) while employed in other activities.

Statements $1 \mathrm{a}$ and $1 \mathrm{~b}$ are not quite the same, but seventeenth and eighteenth-century writers often identified food with subsistence, or at least linked them very closely, so it frequently seems more a matter of chance than of deliberate choice whether a particular writer used version 1a or version 1b. For example, Hume took $y$, in my notation, as the number 'the land will support', but $x$ as the number needed in agriculture plus those who supply 'the more necessary manufactures' to the agricultural workers, rather than to the whole population $(1955,6)$, a notion that falls between the two versions defined above. Steuart cast an almost identical statement in terms of food alone, on the lines of statement 1a, but described those not required to produce food as 'free hands', which would fit better with a definition based on statement $1 \mathrm{~b}$. Where appropriate, therefore, I shall refer to 'statement 1 ', treating statements $1 \mathrm{a}$ and $1 \mathrm{~b}$ as if they were synonymous.

Statement 1 clearly defines a notion of a surplus, but of a very specific kind. It is defined in physical terms and avoids problems of valuation by comparing numbers of people, producers and consumers of food or subsistence goods, rather than physical or value quantities of output. It would be possible to recast the definition in terms of labour time, rather than people, but the writers discussed here did not do so. The surplus defined by statement $1 \mathrm{a}$ arises in agriculture, but only because food is produced by the agricultural sector and the

\footnotetext{
2 'Men' because that is the word the writers discussed here used, as in Hume $(1955,111)$ 'men, both male and female'.
} 
definition is cast in terms of food. Similarly, the surplus defined by $1 \mathrm{~b}$ arises from the industries which produce necessary subsistence goods, by definition. There is no implication that other sectors are 'sterile', that profits or rent arise exclusively from subsistence production, or anything of the sort.

The purpose of this paper is, first, simply to point out the near ubiquity of this very specific form of surplus in late seventeenth- and eighteenth-century writings on economics and, second, to examine the way it was used. I will argue that it mainly served as a starting point for discussion of the relation between agriculture and the rest of the economy, ${ }^{3}$ a natural focus of concern in a period in which non-agricultural activities were growing rapidly in Britain and elsewhere, but in which agriculture was still the largest sector in the economy. I will also argue, more briefly, that this particular concept of surplus is not well adapted for discussion of the distribution of income, in contrast to ideas of surplus developed later by, for example, Marx and Sraffa. The treatment is necessarily very compressed, but it may serve to pick out some common themes. The main focus will be on the writers listed above (Petty, Cantillon, Hutcheson, Hume, Steuart, and Smith) who each presented some immediately recognizable form of statement 1. Quesnay did not, because his 'net product' was defined in value terms as the excess of the value of output over costs. His associate Mirabeau had a version of statement 1 but did not develop it, as did Law and Turgot. They will be mentioned briefly by way of comparison and for completeness.

I will argue that there is a progressive development of thinking about the social division of labour from Petty to Smith, which shows up clearly in the treatment of agricultural surplus. Petty posed the question but made little progress with it, Cantillon set it in the context of a worked-out analysis of an essentially static, agrarian economy, Hume and Steuart took a contrasting line, emphasizing the way commerce unlocks the dynamic potential of agriculture. Smith drew the threads together, with a new emphasis on the role of capital accumulation. By contrast, the particular concept of an agricultural surplus embodied in statement $1 \mathrm{a}$ (or the related $1 \mathrm{~b}$ ) played little role in the development of distribution theories.

\section{Luxury}

Statement 1 only makes sense if there is a definite amount of food (statement 1a) or necessities more generally (statement $1 b$ ) which is required per person or per household. In most seventeenth and eighteenth century versions of this notion of surplus there is an additional assumption, implicit or explicit, that people will not normally consume more than this required amount, so that there is a definite connection between the production of food (or necessities in general) and population. Adam Smith was quite explicit about this, both in the

\footnotetext{
3 Aspromourgos (1996) calls this 'the social division of labour', and uses it (with distribution) as one of two headings for a discussion of economics in this period.
} 
Theory of Moral Sentiments and the Wealth of Nations. 'The rich man consumes no more food than his poor neighbour. ... The desire of food is limited in every man by the narrow capacity of the human stomach' (1776 180; see also 1759 184). As income rises above subsistence level, spending shifts to other things. Smith, again, was very clear that the desire of food is limited 'but the desire of the conveniences and ornaments of building, dress, equipage, and household furniture, seems to have no limit or certain boundary' (1776 180).

There is a connection here with a literature about 'luxury' which goes back at least to the ancient Greeks but which was very alive in the period under discussion. The luxury debate was, generally speaking, cast in moralistic terms, with little economic content. Thus Plato thought that the desire for luxuries led to an unlimited desire for wealth, hence to cities that were fevered and uncontrollable. A succession of ancient and medieval authors followed his lead in condemning luxury as a source of corruption and conflict. Embedded in much of this literature, from Plato on, is the idea that the desire for necessities is limited, hence manageable, while the desire for luxuries is not.

In the early modern period however, particularly in Britain, an opposing view emerged which saw the desire for luxuries as a good thing, because it stimulated production and trade. This was the attitude, for example, of Nicholas Barbon, in the late seventeenth century, who distinguished between the (limited) 'wants of the body' - necessities - and the (unlimited) 'wants of the mind'. 'Man naturally Aspires, and as his Mind is elevated ... his Wants increase with his Wishes, which is for every thing that is rare, can gratifie his Senses, adorn his Body, and promote the Ease, Pleasure, and Pomp of Life' (1690 14). Barbon's focus was on trade and he presented no clear idea of an agricultural surplus, but the idea of a limited demand for necessities but an unlimited demand for other things is clearly there, as in Smith, and as it is implicitly in other writers. Mandeville, in the early eighteenth century, took this line of argument to a scandalous extreme expressed in the subtitle of his Fable of the Bees: or Private Vices, Publick Benefits. Many of the writers discussed here, notably Hutcheson, Hume and (less obviously) Smith, were explicitly or implicitly responding to the luxury debate while trying to avoid the condemnation that Mandeville had attracted (on Smith see Brewer 2006).

\section{The social division of labour}

Statement 1 puts the focus on the relation between those who produce food or necessities and the total population they support. The relation between agriculture and the rest of the economy took centre stage. In a much broader sense, the relation between town and country, between traditional rural ways of life and the growing world of trade, manufacturing and luxury consumption, was a central theme of cultural and political discussion in Britain and elsewhere over several centuries, from the attempts of Tudor monarchs to force the nobility to 'continue the ancient and laudable custome of the Realme' by staying in their country estates, away from the temptations of the city (cited in Lubbock, 1995, 43), to the jeremiads 
of Cobbett in the early nineteenth century. Smith stands at a turning point. The relation between town and country is a recurring theme of the Wealth of Nations, but Smith's emphasis on the mobility of capital and on the consequent equalization of profits between agriculture and other sectors was a step towards treating agriculture as a business like any other. His successors, notably Ricardo, gave a special role to agriculture, but in a new framework in which diminishing returns in agriculture matter simply because of their impact on the system-wide profit rate, not because agriculture has any particular socio-political role.

\section{Petty}

Petty seems to have been the first to present a notion of surplus on the lines of statement $1 .{ }^{4}$ For example, 'if there be 1000 men in a territory, and if 100 of them can raise necessary food and raiment for the whole 1000' (Petty 1899 I: 30). ${ }^{5}$ This example, the first and best-known of several in Petty's works, is part of a discussion of policy towards the indigent and unemployed. He thought that those who are unable to work should be provided for, while the 'lazy and thievish' should be 'restrained and punished' (I: 29), but he was worried that there might not be enough jobs for all those who are genuinely willing and able to work. Of the 1000 men in his hypothetical example, only 100 are needed to provide subsistence ${ }^{6}$ while 200 produce for export markets, 400 produce luxuries - the 'ornaments, pleasure and magnificence of the whole' (I: 30) - and 200 are 'governours, divines, lawyers' and the like. Petty's illustrative numbers leave 100 people unaccounted for, and work should be found for them.

The role of surplus here is essentially secondary and negative - since only 100 are needed to provide subsistence for the whole, there is a potential problem in finding work for the rest. The limitations of the argument should also be noted. The flows of income and spending that underlie the example are not considered at all. Thus, if 200 are employed in export industries, the corresponding imports might be expected to displace domestic employment, but Petty did not take that into account. Nor did he consider the financing of the public works he advocated, beyond saying that it would be 'safer' (from a public order viewpoint) to 'afford [the unemployed] the superfluity which would otherwise be lost and wasted, or wantonly spent' (I: 31). He does not seem to have considered that spending, however 'wanton', creates work and that diverting spending to public works might crowd out other forms of employment. To say this is not to criticise Petty - no such analysis existed at the time - but to warn against reading more sophisticated treatments of surplus into Petty's very crude version.

\footnotetext{
${ }^{4}$ Aristotle had something a little like it., cited by Smith (1776 388).

${ }^{5}$ I have modernized punctuation and capitalisation in quoted extracts.

${ }^{6}$ The assumed rate of surplus is extraordinarily high for the seventeenth century - a mere one hundred workers in the subsistence sector support nine hundred others, including two hundred in superior social positions. The numbers are only illustrative, of course, but they do make it hard to take the argument seriously.
} 
A few years later, he produced a rather similar line of argument in the concluding chapter of Verbum Sapienti, titled 'how to employ the people, and the end thereof'. To 'enrich the kingdom and advance its honour', food and necessaries should be produced by 'few hands' since 'he that can do the work of five men by one, effects the same as the begetting four adult workmen' (I: 118). The rest of the population will have to work to earn their living, and they should 'raise such commodities as would yield and fetch in money from abroad' (I: 119) This plainly mercantilist aim, however, had its limits, and Petty's conclusion reveals how different his cast of mind was from that of later writers.

But when should we rest from this great industry? I answer, when we have certainly more money than any of our neighbour states. ... What then should we busy ourselves about? I answer, in ratiocinations upon the works and will of God, to be supported not only by the indolency, but also by the pleasure of the body, and not only by the tranquility, but serenity of the mind. (I: 119)

To understand Petty's approach, it helps to recall his approach to population theory. He was closely associated with the work of John Graunt, one of the founders of modern demography, who collected evidence on birth and death rates. Petty seems to have treated the rate of population growth determined by the difference between birth and death rates as something like a natural constant. He was prepared, for example, to project it forward for centuries, and to project it backwards to show how population had grown since the time of Noah's ark. Unlike later writers who treated population as endogenous, Petty saw population as essentially exogenous at any given date.

The given population is the main resource of the kingdom, but only if it can be put to work. In a pioneering exercise in human capital theory, he estimated actual and potential income by applying an assumed level of earnings per head to the total population and calculating the corresponding capital value. In Political Arithmetick, for example, he took the estimated population of England, excluding children under seven 'from whom little labour is to be expected' together with those whose rank or position excludes them from labour (I: 307), and calculated the amount each could earn if they were fully employed, to arrive at a total potential income. An estimate of the amount each could 'superlucrate' (save) shows how fast the wealth of the country could grow (I: 308). Again, the naïveté should be noted - Petty treated saving in aggregate as a simple summation of individual saving with no consideration of the form in which saving would be held or the uses it might be put to.

Petty had little to say about how the given population is in fact allocated to different jobs. He had decided views about the most productive tasks for the unemployed to do - import substitution was the best way to create jobs - but little in the way of argument to justify them. If productivity in the production of subsistence goods is high then people can do other things, but those who are not required to produce subsistence must be found some form of useful employment, if only to avoid the danger of civil disturbance. In sum, he posed the question of the social division of labour without making much progress in explaining it. 


\section{Law}

Law presented an argument rather like statement 1, though it is not quite the same and will therefore not be discussed at length.

Suppose an island belonging to one man, the number of tenants a 100, each tenant 10 in family, in all a 1000; by these the island is labour'd, part to the product of corns, the rest for pasturage: Besides the tenants and their families, there are 300 poor or idle, who live by charity. (1705 97)

The tenants, we learn later, only work half the year, so it seems that 1000 working half time can provide for 1300. It becomes clear, however, that some of the produce is exported and other goods imported. The proprietor's consumption, which must be assumed to include luxuries, is not separately accounted for, nor is it clear that the 1300 people mentioned are the whole population. Law's statement at most sets a lower bound to the true surplus. Law presented the example to argue that by creating money the proprietor can provide employment, both for those who presently live by charity and for the tenants during their idle times, either processing local produce for export or producing import substitutes. The point here, apart from completeness, is to show that there was a continuing tradition of concern over employment which perhaps stems from Petty's analysis. The notion of surplus, however, played little role in the bulk of Law's analysis.

\section{Cantillon}

In his Essai sur la nature du commerce en général, Cantillon ${ }^{7}$ set out a calculation very similar to Petty's, in almost exactly the form of statement 1 . Referring to data in the (now lost) appendix, he claimed that 25 adults could provide the necessaries of life for 100, according to what he called the 'European' standard. Half of the population are excluded from manual work on account of age or infirmity or because they have other sources of income, leaving 25 of the hundred 'who are capable of working but would have nothing to do' in the provision of subsistence (1755 87). The assumed rate of surplus is very much lower than Petty's and much more in accord with what we know of productivity at the time.

He then asked what those who are not required to produce subsistence should do, abstracting initially from the economic mechanisms which determine what they will in fact do. They could produce luxuries of any sort, but if they were to produce durable goods they would add to the nation's wealth in a lasting way, especially if they were to mine gold and silver which are particularly durable and 'can always be exchanged for the necessaries of life' (89). Equally, they could produce goods for export, in order to import gold and silver in exchange.

\footnotetext{
${ }^{7}$ I deal with Cantillon rather briefly here, since I have discussed him at length elsewhere (Brewer 1992).
} 
Cantillon justified these uses of labour by arguing that the relative greatness of states is determined, at least in part, by the reserve stock which they can call on in emergencies, and that stocks of gold and silver are the best reserves to hold since they can be used to buy anything. Export markets, however, are limited, and those who cannot produce for export are better employed producing luxuries for domestic consumption than left idle (89-91).

This much follows Petty closely but the context is quite different, as Cantillon signalled by continuing: 'it is always the inspiration of the proprietors of land which encourages or discourages the different occupations of the people' (93), linking the abstract discussion of what people should be employed to do with his analysis of the determinants of what they actually do.

The landlord stands at the centre of Cantillon's analysis. In a central passage, Cantillon considered a self-sufficient estate which served as a model of a whole economy.

If the owner of a large estate (which I wish to consider here as if there were no other in the world) has it cultivated himself he will follow his fancy in the use of which he will put it. (1) He will necessarily use part of it for corn to feed the labourers, mechanics and overseers who work for him, another part to feed the cattle, sheep and other animals necessary for their clothing and food or other commodities according to the way in which he wishes to maintain them. (2) He will turn part of the land into parks, gardens, fruit trees or vines as he feels inclined and into meadows for the horses he will use for his pleasure, etc. (1755 59)

The landlord's tastes determine the way he uses his estate, subject to two constraints: first, the amount of land is fixed, so using it for one purpose prevents its use for another and, second, the workforce must be maintained, so a decision to set people to work at a particular job is equivalent to a decision to devote the necessary resources to providing (conventionally determined) subsistence. Note that the division of land between subsistence and other uses is not the same as the division of the labour force implied by statement 1 . The land might be wholly used for subsistence production despite a high rate of surplus in the terms of statement 1 if those not directly involved in agriculture are employed as servants and the like and thus have to be fed. A market system, Cantillon argued, was just the same. Landowners are the only people with significant disposable income, so landlords' tastes, working through the market, determine the allocation of land, the only scarce resource, and the occupations of the population.

Population adjusts to the demand for labour with living standards at a level set by social convention, because people do not marry unless they can maintain their family at an acceptable level. The land can support a certain maximum population at the given consumption level. However, not all the land may be devoted to the support of human beings. If horses are extensively used for transport, for example, land is diverted from feeding people to feeding horses. The population which is the base for the surplus calculation described 
above is endogenous, depending on the whole complex of landlords' spending decisions. Trade brings in further issues. If food is exported it feeds people abroad, where they constitute potentially hostile military manpower. Production of manufactures for export, by contrast, allows imports of food and builds up population and hence military potential beyond what the land could otherwise support.

The 'fancies' of landlords, then, govern the allocation of resources but have unplanned consequences for the position of the nation as a whole. The relevant conflict is not between classes but between private and public interests. As in Petty, the social division of labour is central, but Cantillon had a well developed and consistent model of the determinants of allocation with land, not labour, as the scarce resource.

\section{Hutcheson, Hume and Steuart}

The notion of a potential surplus in agriculture plays a central role in Hume's economics. 'The land may easily maintain a much greater number of men, than those who are immediately employed in its culture, or who furnish the more necessary manufactures to such as are so employed' (1955 6). Steuart agreed. 'One consequence of a fruitful soil, possessed by a free people, given to agriculture and inclined to industry, will be the production of a superfluous quantity of food, over and above what is necessary to feed the farmers' (1767 42). An agricultural surplus can feed a non-agricultural population of 'superfluous hands' (Hume) or 'free hands' (Steuart). Steuart discussed the number of 'free hands' relative to the numbers of farmers in Britain (1767 51-5), trying to turn the $x$ and $y$ of my statement 1 into real numbers. Steuart followed Hume very closely in the arguments discussed here (Brewer 1997) so I shall concentrate on Hume.

Not only can farmers produce more food than they need for subsistence, they can produce more than they want to consume. If there is nothing they want to buy and no effective way of forcing them to work to produce a surplus, they will not do so. A potential surplus need not be produced at all.

Where manufactures and mechanic arts are not cultivated, the bulk of the people must apply themselves to agriculture; and if their skill and industry encrease, there must arise a great superfluity from their labour beyond what suffices to maintain them. They have no temptation, therefore, to encrease their skill and industry; since they cannot exchange that superfluity for any commodities ... . A habit of indolence naturally prevails. The greater part of the land lies uncultivated. (Hume 1955 10; for an almost exactly parallel statement see Steuart 176741 )

For Hume, this was not simply a theoretical point, but the starting point for economic development. 'In the first and more uncultivated ages of any state, ere fancy has confounded her wants with those of nature, men, content with the produce of their own fields, or with 
those rude improvements which they themselves can work upon them, have little occasion for exchange' (1955 42). In his History of England he described the Ancient Britons as 'ignorant of all the refinements of life', so 'their wants and their possessions were equally scanty and limited' (1754-61 I: 5). After the Anglo-Saxon invasion, things went back to much the same state, since the 'refined arts' were unknown (I: 16). Steuart too thought that many parts of Europe were still held back by 'moral incapacity', that is, by lack of incentives (1767 42).

The process of economic development (to use the modern term) consists of a parallel development of agriculture and manufacturing, in which an agricultural surplus feeds the manufacturing sector, while the desire to buy manufactured goods provides the agricultural sector with a reason to produce such a surplus.

Every thing in the world is purchased by labour; and our passions are the only cause of labour. When a nation abounds in manufactures and mechanic arts, the proprietors of land, as well as the farmers, study agriculture as a science, and redouble their industry and attention. (Hume 1955 11)

The problem, however, is to get the process started. If no attractive goods are on offer, farmers will not produce a surplus and there will be no manufacturing sector, no market for manufactured goods, and no opportunity to learn more sophisticated skills. An external stimulus is needed. 'In most nations, foreign trade has preceded any refinement in home manufactures. ... Thus men become acquainted with the pleasures of luxury and the profits of commerce' (13). 'Had [our neighbours] not first instructed us, we should have been at present barbarians; and did they not still continue their instructions, the arts must fall into a state of languor, and lose that emulation and novelty, which contribute so much to their advancement' (78-9). Steuart took a similar line, working through an example in which a hypothetical country 'of great simplicity of manners' is visited by traders with 'instruments of luxury and refinement. ... those who formerly lived in simplicity become industrious', and output increases (1767 166-71; see also 38-41).

In Hume's version, a taste for luxury stimulates more effort in agriculture, but it also stimulates an irreversible process of learning in both sectors and a general change in the 'manners and customs' of the country. So, faced with the argument that international trade was risky because access to external markets might be cut off, he replied that artisans who had developed skills for the foreign market could find something to sell in the home market 'if the spirit of industry be preserved' (1955 80). Continued openness to trade is important not to retain static gains from trade but to promote further development through emulation and international competition. Steuart took a rather less sanguine view, partly because his different theory of money led him to worry about balance of payments problems, but he too saw development as irreversible. The 'statesman' should redirect activity towards the 'inland trade' if the balance of trade became unfavourable, but it is clear that this did not mean reverting to 'ancient simplicity'. 
The main theme of Hume's analysis of development is the idea that farmers are more productive if they get the surplus and can use it to buy things they want, but he recognized that farmers might have to produce a surplus in order to pay rent and, more generally, that farmers might simply be forced to produce a surplus and hand it over to others. There are two elements to his treatment of the issue. First, he argued that force was inefficient. 'It is a violent method, and in most cases impracticable, to oblige the labourer to toil, in order to raise from the land more than what subsists himself and family. Furnish him with manufactures and commodities, and he will do it of himself' $(1955,12)$. Second, he recognized that feudal landlords did extract some of a very meagre surplus, but argued that in the absence of attractive manufactures they used the money to maintain gangs of unproductive retainers and to fight each other. When attractive luxury goods were introduced, at first from abroad, landlords moved to the towns and bought manufactures with income previously wasted on idle retainers. Luxury led to economic development and to political change - it was, according to the History, the main reason for the decline of feudalism (175461 IV: 385).

Hume's main concern was with the size and growth of the surplus, but he also discussed alternative uses for it. Having established that a surplus supports 'superfluous hands', he asked whether there is a conflict between power and plenty, that is, between maintaining soldiers and enjoying luxury goods. He cited Sparta, where the Helots were forced to support a population of Spartans who lived frugal lives devoted exclusively to war (1955 8-9), but claimed that Sparta was a freak case. In general, a taste for luxury increases the power of the state because it maintains a reserve of manpower in the manufacturing sector which can be switched to military purposes when required. Wartime taxation forces cuts in luxury spending, the manufacturing labour force is reduced, and those who become unemployed have to join the army. In times of peace, the population can enjoy luxuries and farmers produce a surplus to exchange for manufactures, without impairing the ability of the nation to defend itself in time of war (12-13).

Hume and Steuart, then, both set out statement 1 in almost exactly the same way as Petty and Cantillon, $x$ men can support $y$, but they emphasized that the fact that a surplus can be produced is no assurance that it will be. The size of the surplus is endogenous and so is the number of 'superfluous' or 'free' hands that will be supported - the ratio of $y$ to $x$ in statement 1 is not a premise of the argument but a conclusion. The notion of agricultural surplus becomes the central organizing principle in a pioneering theory of economic development.

Hume's economic writings were independent of Cantillon, whose Essai was written before Hume's main economic writings but published after them, but may well have been influenced by Francis Hutcheson's critique of Mandeville and, more distantly, by the Fable of the Bees itself. Mandeville had claimed that national prosperity depends on vice. Without vice, he argued, there would be no demand for anything beyond bare necessities, population would shrink, and those who remained would be confined to a life of 'slothful Ease and stupid 
Innocence' (1970, 200). Mandeville, in turn, may perhaps have drawn on Petty's worry that part of the population may be left unemployed if there is not enough for them to do. Mandeville's argument depends on listing ways in which 'vice' creates employment (thus theft makes work for locksmiths) without considering that people who do not need to fit locks may spend the money on something else. Some version of statement 1 must be implicit in the Fable of the Bees, but it is never made explicit.

In his reply, Hutcheson set out a version of statement 1: 'It is obvious to all, that in a nation of any tolerable extent of ground, three fourths employed in agriculture will furnish food to the whole' $(1726,139)$. Rather than be idle, most would choose to work to obtain 'conveniencies and elegancies of life', allowing many to support themselves by producing goods which are not strictly necessary. He agreed with Mandeville that confining production to necessities would be pointless, since 'there would be no knowledge of arts, no agreeable amusements or diversions; and they must all be idle one half of their time ${ }^{8}$ (139), but denied that moderate enjoyment of luxuries could be seen as a vice.

\section{Mirabeau and Turgot}

Mirabeau had a version of statement 1 in his Mémoire sur L'Agriculture, which was included in the edition of L'Ami des Hommes published in 1760 (at a time when he had just started working closely with Quesnay). 'L'Agriculture est l'unique manufacture où le travail d'un seul ouvrier fournit à la subsistence d'un grand nombre d'autres qui peuvent vaquer à d'autres emplois' (1756-60 13). As it stands, this is part of a passage praising agriculture in a general way, and is not developed further. Quite a few pages on, the theme returns: "plus l'industrie \& la richesse des entrepreneurs de culture épargne de travail d'hommes, plus la culture fournit à la subsistence d'autres hommes. ... Ces autres hommes sont d'autant plus disponibles pour tout autre exercise, pour les différents professions, pour la guerre, pour les travails publiques, \&c' (25-6). There is here a recognition of the implications of agricultural surplus for the scale of other sectors, in terms reminiscent of Hume (whose work Mirabeau and Quesnay would have known). However, between the two passages cited, Mirabeau discussed the surplus arising in agriculture, and its relation to other sectors, in value rather than physical terms (like Quesnay), expressing the surplus as the excess of revenue over money costs, so his main line of argument falls outside the tradition under discussion here.

Turgot should also be mentioned, but need not be discussed at length. In his early unfinished work On Universal History (1973 61-118), written in the early 1750 s, ${ }^{9}$ he presented a version of statement 1 , albeit only in passing and in the context of a broad discussion of the history of

\footnotetext{
${ }^{8}$ If there are no manufactures farmers only work half the time, not three quarters as the previous quotation might suggest, because they no longer produce raw materials for manufacturing.

${ }^{9}$ At almost exactly the time Hume was writing the essays cited here.
} 
mankind. In a discussion of the transition from the hunting to the pastoral stage of history, he asserted that 'herds sustained more men than were required to look after them' (67), but used this fact only to argue that it became possible to detach a military force from the rest of the community to conquer others and force them to do the work of tending the herds. After the later transition to agriculture 'the land can sustain many more men than are necessary in order to cultivate it ... hence people who are unoccupied; hence towns, trade, and all the useful arts and accomplishments; hence more rapid progress in every sphere' (69). These are important insights but Turgot did not develop the argument any further. In his later Reflections on the Formation and Distribution of Wealth he followed Quesnay's lead in treating the agricultural surplus in value terms.

\section{Smith}

Adam Smith too noted the importance of a marketed surplus of food.

When by the improvement and cultivation of the land the labour of one family can provide food for two, the labour of half the society becomes sufficient to provide food for the whole. The other half, therefore, or at least the greater part of them, can be employed in providing other things, or in satisfying the other wants and fancies of mankind. (1776, 180)

The reference is to food because the quoted extract is part of a discussion of agriculture in relation to population and economic development. The preceding paragraphs argue that other necessities of life are relatively easy to produce at a basic level if there is enough food, so food is the limiting factor in population growth. A growing marketed surplus of food is matched by a corresponding growth in manufacturing, where the main benefits of the division of labour are felt, so agricultural growth leads to economy-wide growth of total and percapita output.

Where Hume thought that farmers might not produce a surplus for sale because there was nothing they wanted to buy, Smith insisted that people are always willing to sell any surplus of food over their own needs to satisfy their 'endless' desires.

The desire of food is limited in every man by the narrow capacity of the human stomach; but the desire of the conveniences and ornaments of building, dress, equipage, and household furniture, seems to have no limit or certain boundary. Those, therefore, who have the command of more food than they themselves can consume, are always willing to exchange the surplus, or, what is the same thing, the price of it, for gratifications of this other kind. What is over and above satisfying the limited desire is given for the amusement of those desires which cannot be satisfied, but seem to be altogether endless. 
Both Hume and Smith faced a problem in explaining why development had taken so long. Why were the potential gains from an agricultural surplus not exploited much more quickly? Hume's answer was that tastes were slow to develop and that attractive manufactured goods only became available very slowly. His History spelled it out - in Elizabethan times, for example, demand for things like pocket watches and silk hose was expanding, and so on, stage by stage.

In Smith's story, by contrast, the rate of development is governed by the rate of accumulation of capital. Agricultural improvement involves heavy fixed investment in clearing, draining, enclosing, and manuring the land, and in working animals, farm buildings, and equipment (1776 280-2), as well as investment in circulating capital. The corresponding expansion of industry requires investment in wage advances, materials, equipment, buildings, and so on. Growth is impossible without saving and investment, which are ensured in 'all tolerably quiet and peaceable times' by the 'uniform, constant, and uninterrupted effort of every man to better his condition' (343). Growth, then, is normal but slow, since the fraction of income saved is low in all but the exceptional conditions of new colonies. For example, Smith discussed the opportunities created for Scottish agriculture by the union of Scotland and England, but argued that the response required a 'long course of frugality and industry' (239) which he expected to take a further fifty years, although the union was already fifty years old when he wrote. Steady, continuing growth emerged naturally from Smith's framework. Hume, by contrast, had little or nothing to say about investment in productive activities (see Brewer, 1997).

Smith's account of the slow development of feudal Europe, however, is much closer to Hume's than appears at first sight (Brewer, 1998). Large landowners are unlikely to invest in agricultural improvements or to do the job well if they do. Tenants had no security of tenure and thus no incentive to invest. The 'policy of Europe' discriminated in favour of towns, but they were held back by the backward state of agriculture, that is, the lack of the agricultural surplus defined by statement 1 . Only the possibility of trading on a relatively wide scale allowed towns to develop at all.

The inhabitants of a city, it is true, must always ultimately derive their subsistence, and the whole materials and means of their industry, from the country. But those of a city, situated near either the sea coast or the banks of a navigable river, are not necessarily confined to derive them from the country in their neighbourhood. They have a much wider range, and may draw them from the most remote corners of the world. (1776 405)

The development of manufactures ultimately undermined feudal structures and created better incentives (1776, bk 3, ch 4), just as in Hume (who Smith credited: 1776 412), leading to more secure agricultural tenancies and thus to agricultural development. All this is in contrast to the 'natural' or undistorted progress of opulence exemplified by new colonies, in which agricultural development takes the lead. Agricultural surplus thus plays an essential role in Smith's story. 


\section{The social division of labour: overview}

In one sense, of course, statement 1 is trivial (Vaggi 1987 96). In the age of Versailles, noone could doubt the ability of the economy to support unproductive consumers. None the less, it focused attention on an important set of issues. On the one hand, it emphasised that $x$ men are indeed needed to feed $y$, and thus that the productivity of agriculture matters. In this perspective it was impossible to think, as some naïve mercantilists did, that overseas trade was the only source of national wealth. On the other hand, if only $x$ are needed to support $y$, one has to think about what the others do, and hence about the relation between industry and agriculture, town and country, necessities and luxuries. Petty saw these issues, though he offered few answers. The other writers discussed here, from Cantillon to Smith, grappled with them. Cantillon provided what is perhaps the first analysis of an economy as an integrated system, held together by his analysis of the way the allocation of resources responds to changes in demand and by his account of the flows of spending between town and country (the ancestor of Quesnay's Tableau Économique). Hume complemented Cantillon ${ }^{10}$ with a dynamic historical vision of the process of development centred on the role of trade and of luxury production as a motivating force. Smith gathered the story together with a new emphasis on the role of capital accumulation.

\section{Surplus and Distribution}

There is an important school of commentators who identify a 'surplus approach' in the history of economics, and who link surplus to distribution. Thus, for example, Garegnani (1987 560) argues that the surplus approach had its origins with Petty and Cantillon, 'found its first systematic expression' in Quesnay, and became dominant with Smith. It would not be appropriate to go into detail here about surplus theories in general, but it can be said that the basic idea is that non-wage incomes are equal to total income minus wages, and that this tautology can be given content by treating total income and wages as fixed in some way prior to the determination of non-wage incomes, which emerge as a remainder or surplus. It is natural to ask whether the particular concept of surplus found in statement 1 throws any light on the development of distribution theories in the period under discussion, and in particular whether seventeenth and eighteenth century writers linked this particular concept of surplus to the distribution of income. The answer is in general that they did not. The notion of agricultural surplus found in the literature of the time is well adapted for the analysis of intersectoral relations, but not for the analysis of distribution between types of income.

Some extreme cases will illustrate the point. An agricultural surplus is indeed a necessary condition for the existence of other types of income. If farmers produce only just enough to feed themselves, there could be no non-agricultural incomes and no non-producers at all. This

\footnotetext{
${ }^{10}$ Although Hume wrote later his work was published first.
} 
is a case that Hume implicitly considered. A positive (agricultural) surplus, however, could simply accrue to the farmers who produce it, to be sold in return for manufactured goods, with $x$ farmers supporting $y--x$ non-farmers. In this case, again implicitly considered by Hume, it would not be sensible to link the agricultural surplus to distribution between income types at all. At the other extreme, suppose that agricultural producers are all wage earners, that the wage is set at bare subsistence, and that the surplus all accrues to landowners and/or capitalist farmers. Non-wage incomes in agriculture then correspond to the food requirements of $y-x$ men for every $x$ employed in agriculture. This is the case which corresponds most closely to the surplus theory of distribution, but it still does not tell us about wage and nonwage incomes in other sectors of the economy. The most natural case would be one in which agricultural workers get enough to buy some non-agricultural goods, but part of the income generated in agriculture goes to profits, rent, and the like, with no close connection between distribution and agricultural surplus.

None of the authors discussed here thought that wages were equal to biological subsistence. Smith, after all, thought that 'a workman, even of the lowest and poorest order, if he is frugal and industrious, may enjoy a greater share of the necessaries and conveniences of life than it is possible for any savage to acquire' (1776 10). Petty had no wage theory at all. He thought that wages ought to be kept down to some sort of subsistence level, but that is not the same as having a theory of what they in fact are. Cantillon discussed different wage levels - real wages in Middlesex were much higher than those in the South of France $(1755$ 38, 71) - but seems to have taken the accepted wage in each area as given, prior to the determination of other economic variables - one of the hallmarks of a surplus theory. He had a mechanism population grows if wages are high, but not if they are low. 'Most men desire nothing better than to marry if they are set in a position to keep their families in the same style as they are content to live themselves' (1755 77). Wages tend to the level that leaves people 'content' to raise a family. Hume had little to say about the determinants of wages, while Steuart claimed that wages were determined by supply and demand, without deriving any very definite conclusions about what this would imply. He thought population was endogenous, as did Smith, but Smith thought of the economy as growing, so a constantly growing demand for labour would keep wages above subsistence. Since Smith treated growth as endogenous, wages were not determined prior to other economic variables. Only Cantillon, then, held a subsistence wage theory in the sense that wages are fixed by a social mechanism prior to other economic variables.

Surplus theories of distribution posit a single magnitude, income, which is distributed between wages and other incomes. It is important to realize what a heroic feat of abstraction is involved in putting the question in this way, and also to realise that it could be posed quite differently. Of the authors discussed here, Adam Smith came closest to conceptualizing income distribution in the way that is now taken for granted, but his key concept of the 'annual produce of the land and labour' includes only material products, and the corresponding 'total revenue' includes the incomes of 'productive' workers only, that is of workers who produce material goods, together with the profits and rents generated by their 
activity. The incomes of 'unproductive' workers - menial servants, bishops, soldiers, and so on, are treated as transfer payments.

Smith stands at the borderline. His notion of total revenue has already been mentioned, but consider the 'invisible hand' passage in the Theory of Moral Sentiments, which focuses on the allocation of food (in line with the surplus notion discussed here). 'The rich ... consume little more than the poor', and the 'rest he is obliged to distribute among ... all those who provide and keep in order all the baubles and trinkets, which are employed in the oeconomy of greatness' (1759 184-5). Luxury spending appears as something qualitatively different from the spending of the poor; it is in effect a mechanism by which command over food is transferred to others. Consider another well known example, this time from the Wealth of Nations. 'That portion of his revenue which a rich man annually spends is in most cases consumed by idle guests and menial servants' (1776 338). The rich man's spending consists of consumption by others. Seen this way, it would be inappropriate to add their incomes together or to think of them as shares of a given total. Riches consist in command of other people's time and attention.

For the eighteenth century it may be inappropriate to think of the distribution of income and of consumption as we now do, implicitly assuming that what one person consumes is denied to others. I have taken Smith as my example, because he was the closest to modern ways of thinking. The point could be made even more strongly for earlier writers. In a hierarchical rural society, the consumption of the rich had a public-good character that is unfamiliar today. 'Hospitality' was considered as a social obligation, albeit one that was in sharp decline by the eighteenth century (Lubbock 1995 ch. 2).

To complete the discussion of distribution in the context of the particular concept of surplus discussed here. I will very briefly survey the main authors concerned.

What has to be said about Petty's distribution theory here is essentially negative. Even if one could justifiably claim that he held a surplus theory of rent (and I am not convinced that one can), it is wholly clear that his treatment of rent was not linked to his version of statement 1 . In a much cited text, Petty imagined a man who raises corn, performing all the necessary operations himself.

I say that when this man hath subtracted his seed out of the proceed of the harvest, and also what himself hath both eaten and given to others in exchange for clothes and other natural necessaries, that the remainder of the corn is the natural and true rent of the land for that year. (1899 I: 43)

There are many difficulties with this very brief assertion, but the main problem is that it is almost entirely isolated and is inconsistent with many other statements about rent in Petty's work, for example his claim that taxes on rent will be passed on to the tenant when the rent is renegotiated (I: 37). There is just one place where Petty set out a version of the argument that 
' $x$ men can feed $y$ ', and also brought rent into the story. He assumed that 100 men can produce food for 1000, giving an apparent surplus of nine tenths of output, but then added 'suppose that rent of land (found out as above mentioned) ${ }^{11}$ be the fourth part of the produce (about which proportion it really is ...)' (I: 89). The inconsistency is obvious. Roncaglia's claim that Petty identified surplus with rent (e.g. 1985 69, 90) seems to me to go much too far. Petty did not have a coherent theory of rent. Aspromourgos's claim that agricultural surplus plays a fundamental role in Petty's analysis, and that it takes the form of an analysis of the social division of labour (1986 42), is much more defensible.

Cantillon is an interesting case. He clearly held that wages are determined prior to rents, implying that rent must be a residual, as he must have realized since he clearly understood the way his model hung together. What is interesting is that he never explicitly said so. He repeatedly assumed that the landlord received a third of the gross produce of a farm, with another third going to labourers' wages and the final third to the farmer, but this is clearly a division, for illustrative purposes, and one which treats the different shares symmetrically. It is probably consistent with his version of statement 1 , in which half of the working population produce necessities, but it is hard to be sure.

Since landlords are at the centre of Cantillon's story, it is natural to ask why he said so little about rents. The example of the isolated estate, cited above, may help to provide an answer. He described how the owner of a self-sufficient estate could personally direct the use of the land and the work of all those it supports, including those who work the land, those who produce manufactures of different sorts, and those who are his personal servants. In the modern language of distributional shares, the wages of those who work the land would not be counted as part of the landlord's rent income, but his spending on manufactures would count as spending out of his income, as would the wages of his domestic servants, but from Cantillon's point of view, this would be an irrelevant distinction. The point is that all those who live and work on the estate are the creatures of the landlord and are set to work to satisfy his wants, however indirectly. In that sense the landlord's 'share' of the produce of the estate is one hundred per cent. A market system, according to Cantillon, achieves exactly the same result, with market prices serving as a mechanism which gives effect to the 'fancies' of landlords. From this point of view the money rent charged to farmers measures nothing very important - it is part of the mechanism, but that is all.

Hume had no definite theory of income distribution. He did discuss the possibility of treating those who cultivated the land as slaves and forcing them to produce a surplus, but thought that the resulting surplus would be small. He recognized rent as an empirical fact, but clearly thought that farmers in Britain in his own day (or some of them) were prosperous and independent, implying that rent did not eat up the whole of the surplus.

\footnotetext{
${ }^{11}$ Presumably a reference to the 'rent as surplus' argument cited above, which is a few pages earlier in the text.
} 
Steuart had more to say about distribution, but what he had to say had little more theoretical substance. He described rent as gross produce minus food for the farmer and his servants, their necessary expenses on manufactures, and a reasonable profit 'according to the custom of every country' (1767 53). He did not make a clear distinction between profit and wages in agriculture, or explain how the 'custom' of the country determined the level of profit. His well known concept of 'profit upon alienation' only confuses the matter further. These comments should not be read as criticism of Hume or Steuart. The distribution of income between functional categories - wages, profits, rent - is not important in itself, in the way that the distribution of well-being (not money income) between different individuals is. In some theories the functional distribution of income plays an important role, but in Hume's and Steuart's it did not.

A notion of surplus is clearly central to Quesnay's economics, but it was not stated in a form which can be equated with statement $1 .{ }^{12}$ He defined surplus (or produit net) in value terms (Vaggi 1987), as the difference between the value of output and costs, allowing him to argue that non-agricultural prices covered costs but no more and thus that only agriculture produced a surplus. Given time for contracts to be renegotiated, this surplus accrues to landowners, after the state and the church have taken their share. ${ }^{13}$ Although a physical notion of surplus on the lines of statement 1 must clearly underlie Quesnay's system, it is not at all clear that he understood the relationships involved. If he had, he could surely not have claimed, as he did, that an increase in agricultural prices would increase the surplus. In his own framework, this does not make sense. If non-agricultural prices cover costs, they must rise in line with any increase in agricultural prices, so the produit net is unchanged in real terms.

Smith, with Turgot, was the first to treat profit as an income share on a par with wages and rent, and thus the first to conceptualize the functional distribution of income in the now familiar way, as a total 'annual revenue' divided into three elements (e.g. 1776 265). His wage theory has already been briefly described. His account of profits and rent need not be

\footnotetext{
12 Quesnay did refer to the hypothetical case of 'un pays où les productions consommables excèdent la consommation qu'en peuvent faire les habitants qui les font naître par leurs travaux' (1958 775), which looks like statement 1 . However, he added that this only applied to an underpopulated but productive country, and was 'difficile à conçevoir'. Elsewhere he remarked that the land 'must not only feed [nourrir] those who cultivate it' but must support the state, the church, the landlords and so on (482), but the second part of the statement is expressed in terms of payments, not numbers of people, and the argument is not developed along the lines under discussion here. It does not seriously threaten the view that Quesnay conceived the surplus in value terms.

${ }^{13}$ Vaggi argues that Quesnay expected farmers to retain some of the surplus even when rents are renegotiated, but that he was reluctant to say so explicitly for political reasons. Either way, the argument presented here stands.
} 
discussed in detail here. ${ }^{14}$ All that need be said is that his distribution theory is not directly linked to his version of statement 1 , which defines a marketable surplus of food arising in agriculture, nor is it, in any reasonable sense, a surplus theory. Smith did, it is true, use the word 'surplus' in setting out his rent theory, but the 'surplus' concerned is the surplus of revenue over profit plus wages.

Such parts only of the produce of land can commonly be brought to market of which the ordinary price is sufficient to replace the stock which must be employed in bringing them thither, together with its ordinary profits. If the ordinary price is more than this, the surplus part of it will naturally go to the rent of land. ... Whether the price is or is not more depends upon the demand. (161-2)

In his discussion of colonies, Smith argued that profits were high because land was abundant and rents low, and that wages in the colonies were high because the demand for labour was growing rapidly as a result of the availability of profitable investment opportunities. In other words, wages, profits, and rent are all interdependent. This cannot be seen as a surplus theory in any but the most tautological sense.

Although Smith stands at the start of the classical tradition, with its three great sources of revenue, he was far from regarding distribution thus conceived as 'the principal problem in Political Economy' (Ricardo 1817 5). As noted above, Smith seems to have thought that the spending of the rich mainly served to support others, either 'idle guests and menial servants' or productive workers, so that it is qualitatively different from the spending of the majority of the population. His 'modern' analysis of the functional distribution of income is balanced by elements reminiscent of earlier eighteenth century writers.

If one starts with a twentieth-century notion of surplus, derived (say) from a Sraffianized Marx or Ricardo, then one can indeed find a variety of predecessors in the seventeenth and eighteenth century, at least in the sense that elements of a surplus theory abound, even if they never quite come together satisfactorily. This is reading history backwards, and is a legitimate thing to do. If, however, one tries to set later developments aside and focus on the period in its own right, not as a mere preliminary to Ricardo and Marx, it looks different. The one clear and consistent notion of surplus that runs right through the period is the notion of an agricultural surplus summed up by statement 1 , which turns out to have at best a very tangential connection to distribution. What is notable is the way the writers of the period, Quesnay excepted, seem to shy away from an explicit surplus theory of rent. At the end of the period, Smith explicitly, even jubilantly, broke with a subsistence theory of wages, emphasising the high and rising levels of real wages in Britain and the even higher levels in the colonies.

\footnotetext{
${ }^{14}$ See Brewer (1995) for fuller discussion and for a demonstration that Smith's theory is more coherent than is often admitted.
} 


\section{Conclusion}

The notion of a marketable surplus of food originating in agriculture, or of a surplus of output over bare necessities (usually identified with the produce of the agricultural sector) played an important part in late-seventeenth and eighteenth century economics. In itself the idea that such a surplus exists is trivial, but the questions it points to are not. Will the surplus be produced at all? How is it transferred to those who consume it? What are the 'superfluous hands' (in Hume's terms) to do? It is impossible to pose these questions without thinking about the economy as a whole, and the way different sectors hang together. The common thread that runs through eighteenth-century discussions of surplus is a concern with the relation between industry and agriculture, between the urban world of commerce and luxury production and the traditional world of the countryside, and with the potential for development arising from their interplay. There is, however, a clear discontinuity between the eighteenth-century view of agricultural surplus discussed here and the later tradition which links surplus to income distribution and pricing. Writers before Smith did not generally conceptualize income distribution in terms of the division of a defined total income between different functional shares, nor was there any consistent tradition linking income shares to the notion of a surplus of this (or any other) sort.

\section{References}

Aspromourgos, T. (1986) 'Political economy and the social division of labour: the economics of Sir William Petty'. Scottish Journal of Political Economy, 33, 28-45.

(1996) On The Origins of Classical Economics: Distribution and Value from William Petty to Adam Smith. London, Routledge.

Barbon, N. (1690) A Discourse of Trade, London: Tho. Milbourne; edition cited: Hollander, J. (ed.), Reprint of Economic Tracts, Baltimore: The Lord Baltimore Press, 1905.

Brewer, A. (1992) Richard Cantillon: Pioneer of Economic Theory. London: Routledge.

(1995) 'Rent and profit in the Wealth of Nations'. Scottish Journal of Political Economy, 42, 183-200.

(1997) 'An eighteenth century view of economic development: Hume and Steuart'. European Journal of the History of Economic Thought, 4, 1-22.

(1998) 'Luxury and economic development'. Scottish Journal of Political Economy, 45, 78-98. 
(2006) 'On the other (invisible) hand ...', University of Bristol Department of Economics Discussion Paper 06/594.

Cantillon, R. (1755) Essai sur la Nature du Commerce en Général. English translation by H. Higgs. London: Macmillan, 1931.

P. Garegnani (1987) 'Surplus approach to value and distribution'. In J. Eatwell, M. Milgate and P. Newman (eds), The New Palgrave Dictionary of Economics, London: Macmillan, 560-74.

Hume, D. (1754-61) History of England. 6 vols. Edition cited: Indianapolis: Liberty Fund, 1983.

— (1955) Writings on Economics. E. Rotwein (ed.), Edinburgh: Nelson.

Hutcheson, F. (1726) 'Letter[s] to Hibernicus', (signed 'P. M.'). Dublin Weekly Journal, Sat. Feb. 4th, 12th, 19th \{sic\}. Edition cited: Collected Works of Francis Hutcheson, Hildesheim: Georg Olms Verlagsbuchhandlung, 1971, Vol VII, pp. 132-69.

Law, J. (1705) Money and Trade Considered with a Proposal for Supplying the Nation with Money. Facsimile reprint, New York: Augustus M. Kelley, 1966.

Lubbock, J. (1995) The Tyranny of Taste. New Haven and London: Yale University Press.

Mandeville, B. (1970) The Fable of the Bees. Edition cited: P. Harth (ed), Harmondsworth: Penguin.

Mirabeau, V.Riquetti, Marquis de (1756-60) L'Ami des Hommes, Avignon, part 5, Mémoire sur l'agriculture; reprinted Aalen: Scientia Verlag, 1970, vol 2.

Petty, W. (1899) The Economic Writings of Sir W. Petty. Ed. C. H. Hull, 2 vols. Cambridge.

Quesnay, F. (1958) François Quesnay et la Physiocratie. 2 vols, Paris: Institut National des Etudes Demographiques.

Ricardo, D. (1817) The Principles of Political Economy and Taxation. Edition cited: P. Sraffa (ed), Cambridge University press, 1951.

Roncaglia, A. (1985) Petty: the Origins of Political Economy. University College Cardiff Press.

Smith, Adam (1759) The Theory of Moral Sentiments. Edition cited: D. D. Raphael and A. L. MacFie (eds), Oxford, Clarendon Press, 1976. 
- (1776) An Inquiry into the Nature and Causes of the Wealth of Nations. Edition cited: A.H. Campbell, A.S. Skinner and W.B. Todd (eds), Oxford, Clarendon Press, 1976.

Steuart J. (1767) An Inquiry into the Principles of Political Oeconomy. 2 vols. Edition cited: A. Skinner (ed.), Edinburgh: Oliver and Boyd, 1966.

Turgot (1973) Turgot on Progress, Sociology and Economics. Ed R. Meek, Cambridge University Press.

Vaggi, G. (1987) The Economics of François Quesnay. Houndmills: Macmillan 